\title{
Resistensi Perempuan dalam Film For Sama: Kajian Timur Tengah Perspektif Feminisme Naomi Wolf
}

\author{
Devi Laila Maghfiroh, Moh. Zawawi \\ Universitas Islam Negeri Maulana Malik Ibrahim Malang \\ 17310191@student.uin-malang.ac.id,zawawi@bsa.uin-malang.ac.id
}

\begin{abstract}
This study aims to describe the form of female resistance from Naomi Wolf's perspective in the film. The approach in this study refers to the concept of Naomi Wolf's feminism, which is specific to the feminism of power. The object of this research is a documentary film with an English subtitle entitled For Sama which is directed by Wa'ad Al-Khateab and Edward Watts. This type of research is qualitative descriptive and library research. The data collection technique uses the watching technique, the listening technique, the reading technique, and the note taking technique. Data analysis through the stages of data reduction, data exposure, and drawing conclusions. The results of this study are that the form of women's resistance in Naomi Wolf's Film For Sama perspective consists of six forms, namely: (1) independence; (2) altruism; (3) persistence; (4) chauvinism; (5) revolutionary; (6) toughness.
\end{abstract}

Keywords: Naomi Wolf; feminism of power; women's resistance.

\section{Intisari}

Penelitian ini bertujuan untuk mendeskripsikan bentuk resistensi perempuan perspektif Naomi Wolf dalam film. Pendekatan dalam penelitian ini mengacu pada konsep feminisme Naomi Wolf, yaitu spesifik pada feminisme kekuasaan. Objek penelitian ini adalah film dokumenter bersubtitle bahasa Inggris berjudul For Sama yang disutradarai oleh Wa'ad AlKhateab dan Edward Watts. Film ini mengungkap realitas konflik Suriah tepatnya di kota Aleppo. Jenis penelitian ini adalah kualitatif deskriptif dan studi pustaka (library research). Teknik pengumpulan data menggunakan teknik tonton, teknik simak, teknik baca, dan teknik catat. Analisis data melalui tahapan reduksi data, pemaparan data, dan penarikan kesimpulan. Hasil penelitian ini adalah bahwa bentuk resistensi perempuan dalam Film For Sama perspektif Naomi Wolf terdiri atas enam bentuk, yaitu: (1) independensi; (2) altruisme; (3) persistensi; (4) chauvinisme; (5) revolusioner; (6) ketangguhan.

Kata kunci: Feminisme kekuasaan; Naomi Wolf; resistensi perempuan.

\section{Pendahuluan}

Resistensi merupakan sikap bertahan, berusaha melawan, tindakan menentang dengan kekuatan dan sumber daya yang dimiliki. Resistensi menjadi salah satu topik yang menarik dalam kajian feminisme. Resistensi erat hubungannya dengan deskriminasi dan ketidakadilan gender. Resistensi adalah respon menolak dan menentang terhadap hukum, stigma, atau stereotip yang mensubordinasi dan memarginalisasi perempuan. Resistensi 
Devi Laila Maghfiroh dan Moh. Zawawi, Resistensi Perempuan dalam Film For Sama: Kajian Timur Tengah Perspektif Feminisme Naomi Wolf

tidak membutuhkan pembenaran akan ketidakberdayaan perempuan, tetapi membutuhkan aksi positif menunjukkan ketahanan dan kekuatan perempuan berbalut estetika femininitas dalam berbagai aspek kehidupan (Irianto, 2003: 292).

Resistensi perempuan lahir sebagai refleksi feminisme kekuasaan. Feminisme kekuasaan menjadi motivasi penyemangat bagi perempuan untuk mengidentifikasi diri melalui femininitas atau keperempuanan yang digenggam bersama-sama dan bukanlah menanggung derita ketidakberdayaan bersama-sama. Resistensi perempuan menunjuk pada potensialnya seorang perempuan yang merupakan cerminan pengalaman hidupnya. Perempuan memiliki daya, kekuatan, dan hak penuh atas hidupnya, bukan terjerembab dalam kesedihan akibat hukum yang terkonstruk sosial masyarakat. Feminisme kekuasaan menegaskan posisi perempuan yang memiliki kuasa penuh atas dirinya dan berperan penting dalam segala aspek kehidupan tanpa meminta izin ataupun memohon (Muslimin, 2019: 125126).

Feminisme merupakan perspektif atau cara pandang, cara pikir, dan ideologi untuk mencapai keadilan gender (Murphy, 2004: 127). Naomi Wolf adalah tokoh penggagas feminisme kekuasaan yang menyuarakan secara lantang daya kekuatan dan ketahanan perempuan serta menolak keras akan ketidakberdayaan perempuan dan penggebrak peran perempuan dalam segala bidang kehidupan. Naomi Wolf menyatakan bahwa kejujuran memandang sisi-sisi gelap perempuan adalah sesuatu yang memberdayakan dan baik secara moral. Naomi Wolf menyatakan perempuan memiliki kuasa bukan berarti perempuan adalah monster dengan senjata tempur yang berat, tetapi aksi agresif yang bersifat positif bagi dirinya dan orang lain (Hearty, 2015: 32).

Wolf menghadirkan dua tradisi feminis, yaitu feminisme korban dan feminisme kekuasaan. Feminisme korban dengan prinsip 'intisari kebaikan perempuan' yang memposisikan perempuan dalam ketidakberdayaan guna mendapat kekuasaan, feminisme ini menurut Wolf bersifat regresif yang memperlambat kemajuan, seharusnya prinsip yang jauh lebih baik adalah 'kejujuran seorang perempuan dalam memandang sisi-sisi gelap dalam diri mereka adalah sesuatu yang memberdayakan dan baik secara moral'. Feminisme kekuasaan menjadikan pengalaman perempuan sebagai refleksi kekuatan dari dalam diri dan menyetarakan kekuasaan yang sama antara laki-laki dan perempuan (Hammer, 2002: 54$55)$. 
Devi Laila Maghfiroh dan Moh. Zawawi, Resistensi Perempuan dalam Film For Sama: Kajian Timur Tengah Perspektif Feminisme Naomi Wolf

Prinsip feminisme kekuasaan menurut Wolf terdiri atas lima prinsip, yaitu: (1) peran besar dalam kehidupan adalah hak yang sama antara perempuan dan laki-laki; (2) perempuan memiliki kuasa penuh atas nasibnya; (3) pengalaman perempuan memiliki arti bukan sekedar omong-kosong; (4) perempuan memiliki kuasa untuk mengungkapkan kebenaran atas pengalamannya; (5) perempuan berhak menerima rasa hormat dalam segala bidang kehidupan (Wolf, 1997: 204).

Dalam kajian feminisme, feminisme adalah menggali, mengkaji, serta menilai peran perempuan dari karya-karya sastra, realita pada masa kini ataupun masa-masa silam. Feminisme memperjuangkan kesempatan bagi perempuan untuk merekonstruksi dunia perempuan dan menawarkan prospek kebebasan di masa depan (Jones, 2009: 14). Film merupakan media massa yang merefleksikan kehidupan sehari-hari masyarakat yang dikemas dengan epik sehingga pesan dapat tersampaikan. Turner mendefinisikan film sebagai representasi fakta realitas masyarakat. Tetapi seiring perkemangan zaman, film tidak melulu tentang realitas, tetapi juga alat untuk membentuk tata sosial masyarakat, termasuk film feminisme. Film bertemakan feminisme memiliki dua fungsi, yaitu sebagai representasi fenomena realitas dalam masyarakat dan membentuk tata aturan yang mampu memberikan keadilan bagi perempuan dan laki-laki (Djajanegara, 2000: 18).

Objek kajian penelitian ini adalah film dokumenter yang tentu merupakan representasi realitas dan fakta yang terjadi dalam film tersebut, yaitu film For Sama oleh Waad Al-Khateab. Film ini menggambarkan resistensi seorang ibu di tengah peperangan Suriah, tepatnya di kota Aleppo dengan segala penderitaan yang ditimbulkannya. Perempuan yang diperankan langsung oleh Waad Al-Khateab sebagai seorang ibu, istri, juga seorang jurnalis. Film ini menunjukkan ketahanan perempuan di tengah kekacauan dengan tetap memerankan gendernya dengan penuh tanggung jawab. Film ini berhasil mendapatkan reward sebagai film dokumenter terbaik tahun 2019 dalam ajang International Documentary Assosicationdi Los Angeles, Amerika. Peneliti tertarik mengkaji objek ini dikarenakan film ini mampu merefleksikan resistensi perempuan yang berjuang di tengah peperangan Suriah, kota Aleppo.

Permasalahan yang akan dipecahkan dalam penelitian ini yaitu "Potret Resistensi Perempuan dalam film For Sama oleh Waad Al-Khateab di tengah Konflik Timur Tengah perspektif Feminisme Naomi Wolf". Berdasarkan pemaparan di atas dan permasalah tersebut, maka tujuan penelitian ini adalah menjelaskan dan memaparkan bentuk upaya 
Devi Laila Maghfiroh dan Moh. Zawawi, Resistensi Perempuan dalam Film For Sama: Kajian Timur Tengah Perspektif Feminisme Naomi Wolf

resistensi perempuan di tengah konflik Timur Tengah dalam film For Sama sebagai kajian timur tengah perspektif feminisme Naomi Wolf.

\section{Metode Penelitian}

Penelitian ini menggunakan pendekatan kualitatif deskriptif dan library research. Metode penelitian kualitatif menggunakan desskripsi dalam wujud kata-kata, seperti analisis dokumen (Tracy, 2013: 6-8). Data kualitatif dapat berupa catatan atau rekaman kata-kata, kalimat atau paragraf, observasi, atau pemaknaan dokumen (Yin, 2011: 8). Penelitian deskriptif bertujuan memberikan gambaran fenomena atau kenyataan sosial melalui pendeskripsian variabel (Achmadi dan Narbuko, 2002: 44). Penelitian dengan pendekatan kualitatif lebih mengutamakan analisis data secara deskriptif (Bailey, 1994: 40). Penelitian kualitatif deskriptif ini bertujuan untuk mendeskripsikan fenomena resistensi perempuan di tengah peperangan Suriah. Pendekatan penelitian yang menjadi acuan peneliti dalam mengkaji objek adalah feminisme perspektif Naomi Wolf yang menyuarakan kekuatan dan resistensi perempuan. Sumber data penelitian adalah film For Sama oleh Waad Al-Khateab sebagai sumber data primer, buku-buku pendukung, artikel, jurnal, dan berbagai literatur yang berkaitan dengan feminisme Naomi Wolf. Peneliti menggunakan teknik baca secara intensif kritis dan teknik catat dalam mengumpulkan data untuk mengidentifikasi resistensi perempuan dan memaparkan secara deskriptif. Teknik validitas data adalah dengan peningkatan ketekunan, triangulasi, dan diskusi teman sejawat. Adapun analisis penelitian terdiri atas reduksi data, pemaparan data, dan penarikan kesimpulan (Miles, Huberman, and Saldana, 2014: 32-33). Dalam tahapan reduksi data, peneliti memusatkan perhatian pada data yang dibutuhkan untuk mengkerucutkan pembahasan dan harus relevan terhadap tujuan penelitian, yaitu peneliti melakukan seleksi data terbatas pada tuturan dan latar yang menggambarkan fenomena feminisme khusus resistensi perempuan dalam film. Pemaparan data dalam penelitian kualitatif adalah naratif/deskriptif. Peneliti memaparkan data secara sistematis dalam bentuk tabel dan uraian serta analisis peneliti. Penarikan kesimpulan ini, peneliti mengambil garis besar hasil pembahasan penelitian berupa deskripsi hasil analisis sesuai tujuan penelitian dan perspektif peneliti terhadap fenomena resistensi perempuan dalam film. 
Devi Laila Maghfiroh dan Moh. Zawawi, Resistensi Perempuan dalam Film For Sama: Kajian Timur Tengah Perspektif Feminisme Naomi Wolf

\section{Hasil dan Pembahasan}

Pada tahapan ini, peneliti akan memaparkan hasil pengumpulan, validasi, dan analisis data dalam bentuk tabel dan uraian analisis serta interpretasi peneliti. Berdasarkan fokus penelitian dengan analisis model Miles dan Huberman, peneliti menyajikan paparan data resistensi perempuan dalam film For Sama menjadi beberapa subbab, sebagai bentuk resistensi. Peneliti memperoleh data beberapa bentuk resistensi perempuan yang didasarkan pada perspektif Naomi Wolf. Adapun pemaparannya sebagai berikut:

Resistensi perempuan dalam film For Sama berdasarkan perspektif Naomi Wolf

Naomi Wolf menegaskan bahwa perempuan haruslah kuat dan berpendirian untuk membuktikan dirinya dengan bebas berkehendak dan melepaskan diri dari hegemoni lakilaki. Dalam perspektif Naomi Wolf, Wolf menawarkan dua tradisi feminis, yaitu feminisme korban dan feminisme kekuasaan. Feminisme korban yang cenderung memperlambat kemajuan feminisme, melahirkan cara pikir cenderung negatif, dan bersifat regresif. Analisis Film For Sama berfokus pada resistensi perempuan perspektif feminisme kekuasaan. Film For Sama merefleksikan perempuan juga seorang ibu yang memiliki independensi dan resistensi yang kuat di tengah konflik Suriah. Film ini mampu mengangkat perempuan sebagai tokoh utama dan tidak mensuborninasi perempuan. Adapun data hasil temuan peneliti adalah sebagai berikut:

Tabel 1. Bentuk resistensi

\begin{tabular}{ll}
\hline Jenis & Bentuk \\
Feminisme & Independensi \\
& Altruisme \\
& Persisten \\
& Chauvinisme \\
& Revolusioner \\
& Ketangguhan \\
\hline
\end{tabular}

Berdasarkan data hasil perolehan peneliti di atas menyatakan bahwa bentuk resistensi perempuan perspektif Naomi Wolf dalam film For Sama terdiri atas tujuh bentuk diantaranya: Independensi, altruisme, berpendirian teguh, nasionalisme, pemberani, tangguh, dan rela berkorban. Adapun pemaparannya adalah sebagai berikut:

\section{Resistensi Independensi Dalam Subjektif Perempuan}


Devi Laila Maghfiroh dan Moh. Zawawi, Resistensi Perempuan dalam Film For Sama: Kajian Timur Tengah Perspektif Feminisme Naomi Wolf

Wolf menekankan bahwa perempuan memiliki kebebasan penuh atas jalan hidupnya, tidak membutuhkan perizinan untuk mencapai kesetaraan gender. Sudah seharusnya perempuan memiliki potensi, bertindak agresif, dan berani menghadapi segala tantangan. Pada titik ini, menuntut perempuan memiliki potensi dan menolak untuk menggantungkan diri. Wolf memberikan motivasi besar untuk kebangkitan perempuan bukan pembenaran atas diri perempuan (Hearty, 2015: 33).

Independensi adalah kebebasan berpikir dan bertindak atas kemauan sendiri. Independensi perempuan merupakan kemampuan dalam diri untuk memaksimalkan segala potensi dan pengalaman yang dimilikinya (Saleh, 2018: 58-59). Independensi perempuan adalah kebanggaan akan identitasnya sebagai perempuan dan memiliki kebebasan berpolitik dan kritis terhadap apapun yang dihadapinya. Independensi menolak atas segala pengeksploitasian terhadap perempuan (Shihab, 2010: 119-121).

Kisah nyata yang terefleksikan dalam film dokumenter For Sama menjadikan perempuan sebagai pusat dan subjek pemeran utama. Di awal pemutaran film, perkenalan tokoh utama perempuan pada 10 tahun lalu.

"[...] That year, I left my family home to study at Aleppo Unversity, my parents told me to be careful, they always said I was headstrong, even reckless " (For Sama, 2019, 01.57).

Monolog di awal pemutaran film tersebut menunjukkan tokoh utama perempuan bernama Wa'ad di sepuluh tahun yang lalu di usia 18 tahun yang memutuskan untuk tinggal jauh dari keluarga untuk mengejar impiannya, di Aleppo University. Perempuan dengan keteguhan hati dan kemauan yang keras memutuskan untuk hidup mandiri tidak lagi bergantung pada orangtuanya, meskipun secara implisit orangtuanya berat dan khawatir atas keputusannya dan tetap memotivasi dan menguatkan hatinya. Independensi Wa'ad tampak pada sikap bertanggung jawabnya sebagai perempuan akan kewajibannya, dapat mengakumulasikan kewajiban dan harapan, serta menjadi penguat diri, keluarga, dan masyarakat.

Independensi perempuan dapat diidentifikasi melalui cara berpikir yang inisiatif, tokoh perempuan tersebut cara menyelesaikan permasalahan, penuh ketekunan, dan keinginan bertindak tanpa bantuan orang lain. Independensi muncul sebagai keyakinan akan kekuatan dan adanya kesempatan. Film For Sama menggambarkan fakta akan kemandirian seorang perempuan. Sosok Wa'ad dengan pasti yakin akan keputusannya melanjutkan pendidikannya jauh dari orangtuanya, Wa'ad bertekad hidup mandiri tidak lagi 
menggantungkan dirinya dengan tinggal bersama orangtuanya. Bahkan dalam tuturan di atas, orangtuanya yakin akan kerasnya pendirian putrinya, Wa'ad yang tidak pernah sembrono dan memiliki keteguhan kuat atas setiap kata-kata yang diucapkannya.

\section{Resistensi Altruisme Perempuan}

Wolf menyuarakan dengan lantang bahwa perempuan harus mampu menghadapi segala tantangan. Perempuan memiliki potensi dan ketahanan yang kuat dalam menghadapi segala tantangan. Perempuan memiliki kebebasan penuh atas tindakan dirinya atau kekuasaan akan segala tindakannya. Sifat baik seorang perempuan adalah inner beauty yang menjadi kekuatan bagi seorang perempuan (Udasmoro, 2018: 22).

Altruisme adalah karakter positif lawan dari egoisme. Altruisme merupakan sifat yang bersumber dari kemurahan hati. Altruisme adalah sikap berupa ketersediaan mendahulukan kepentingan orang lain, simpatik tinggi akan keadaan orang lain. Altruisme perempuan merupakan inner beauty yang muncul sebagai keyakinan akan kekuatan, ketahanan, dan potensi diri. Altruisme bukan hasil dari deskriminasi, akan tetapi secara murni lahir dari hati nurani seorang perempuan (Gula, 2009: 84).

Altruisme yang terefleksikan dalam film For Sama nampak ketika Wa'ad tokoh jurnalis dan seorang ibu di tengah konflik Suriah yang mementingkan keselamatan buah hatinya, Sama. Adapun tuturan yang menggambarkan altruisme tersebut adalah:

Tuturan monolog Wa'ad:

When I hear the Russians warplanes in the sky, it cuts through me. Yes I am scared of dying, but what scares me the most is losing you (For Sama, 2019, 07.23).

Wa'ad di tengah konflik Suriah dengan dentuman bom Rusia yang lumrah menjadi musik kesehariannya tentu berdampak adanya ketakutan akan wafat oleh bom-bom tersebut. Akan tetapi ketakutan terbesar bukanlah kematiannya sendiri, tetapi kehilangan buah hatinya, Sama. Wa'ad memiliki ketakutan terbesarnya bukan tentang dirinya tetapi buah hatinya. Dia lebih mengkhawatirkan keselamatan buah hatinya daripada dirinya sendiri. Hal ini menunjukkan bahwa tokoh wanita Wa'ad akan melakukan segala cara untuk keselamatan buah hatinya, karena dia memiliki potensi. Wa'ad yakin memiliki kekuatan dan ketahanan untuk melindungi buah hatinya, Adapun tuturan lainnya yang merefleksikan altruisme adalah:

Hamzah: "It's the Russian's plan. Up until now, they've been bombing and killing us. Then they say that this is your only option. We have no choice." [...] 
Devi Laila Maghfiroh dan Moh. Zawawi, Resistensi Perempuan dalam Film For Sama: Kajian Timur Tengah Perspektif Feminisme Naomi Wolf

(Monolog Wa'ad) We know this is our only chance to survive. To protect you and all the children. But it also mean all our sacrifices were for nothing. Our future is no longer in our hands. Aleppo is gone (For Sama, 2019, 1.10.10).

Tuturan di atas menunjukkan bahwa adanya kesepakatan yang ditetapkan Rusia, yaitu memberikan satu-satunya pilihan untuk meninggalkan Aleppo untuk menghentikan adanya korban peperangan. Akan tetapi Hamzah, istri Wa'ad mengetahui pasti bahwa hal tersebut hanyalah rencana Rusia. Dan Wa'ad memutuskan untuk tetap meninggalkan Aleppo, kota tercinta demi melindungi anak-anak Aleppo dan Sama. Meskipun Wa'ad sangat berat melakukannya, karena meninggalkan Aleppo artinya pengorbanan selama ini adalah sia-sia. Wa'ad mengetahui benar bahwa meninggalkan Aleppo menjadikan perjuangannya selama ini bertahan di Aleppo menjadi sia-sia, akan tetapi Wa'ad memutuskan untuk melakukannya demi keselamatan buah hatinya dan seluruh anak-anak Aleppo.

\section{Resistensi Persisten Perempuan}

Wolf mendeskripsikan tentang feminisme kekuasaan bahwa perempuan memiliki hak untuk menentukan nasibnya. Perempuan memiliki ketegasan penuh akan setiap apa yang dikehendaki sehingga perempuan tidak perlu meminta izin untuk mendapatkan kesetaraan gender. Perempuan memiliki kuasa yang sama atas dirinya dengan laki-laki. Perempuan memiliki kuasa yang sama dalam mempertahankan pendapatnya (Hearty, 2015: 33).

Persisten berarti tetap hati dan tidak berubah hati terhadap apa yang telah dikatakannya. Persisten artinya ajeg terhadap apa yang dikatakannya dan tidak mudah terpengaruh orang lain ataupun terpancing emosi. Persisten merupakan sikap tegas akan jalan dan langkah yang dipilih. Persisten juga berarti teuh pendirian, yaitu sebagai bukti akan keyakinannya bahwa setiap yang dilakukan itu adalah kebenaran. (Anggraini dan Kusniarti, 2017: 45).

Your grandparents were scared for me, Sama. (in telephone) Wa'ad: "Listen They told me to come home, but I am not going to, No, There's no way they'd let me return here and there's so much I could contribute". (monolog Wa'ad) But I was headstrong back than, so, of course I decide to stay (For Sama, 2019, 15.07).

Tuturan di atas menunjukkan bagaimana khawatirnya kakek neneknya Sama, orangtua Wa'ad, dimana keduanya meminta Wa'ad untuk kembali ke rumah dan terhindar dari dampak peperangan di Aleppo. Akan tetapi, Wa'ad memilih untuk tetap tinggal di Aleppo demi berkontribusi memperjuangkan kebebasan Aleppo. Wa'ad tetap teguh dan kuat pendiriannya untuk tetap tinggal di Aleppo sebagai rumah keduanya, dan tentu berkontribusi 
Devi Laila Maghfiroh dan Moh. Zawawi, Resistensi Perempuan dalam Film For Sama: Kajian Timur Tengah Perspektif Feminisme Naomi Wolf

memperjuangkannya. Wa'ad sangat yakin akan keputusannya tetap tinggal di Aleppo meskipun di tengah konflik berdarah. Wa'ad tetap teguh bertahan di Aleppo, yang telah menjadi rumah baginya mendapatkan ilmu dan kehidupannya. Wa'ad memiliki kuasa dan kebebasan untuk mempertahankan pendiriannya. Wa'ad berkuasa penuh untuk menentukan nasibnya. Wa'ad berhak untuk hidup mandiri dan tidak menggantungkan diri pada orang lain. Wa'ad memutuskan untuk tetap dan teguh atas keputusannya tetap tinggal di Aleppo, meskipun di tengah konflik berdarah yang tak kunjung selesai.

\section{Resistensi Chauvinisme Perempuan}

Wolf berpendapat bahwa perjuangan untuk menghilangkan deskriminasi dan subordinasi kuranglah memberikan dampak yang bermanfaat. Wolf menyatakan esensi perjuangan perempuan adalah sebuah tindakan dan bukti akan kekuatan hakiki gender perempuan yang berdasar pada pengalaman-pengalaman hidupnya. Wolf menyuarakan feminisme kekuasaan untuk membangkitkan perempuan sesungguhnya yang membuktikan akan kekuatan perempuan bukan membenarkan kekuatan perempuan yang menjurus pada kelemahan perempuan (Rahman dan Hearty, 2016: 293).

Karakter chauvinis terefleksikan dalam cara pikir, bertindak, bersikap demi kesetiaan peduli, dan menempatkan kepentingan bangsa di atas kepentingan sendiri (Majid, 2019: 64). Chauvinisme merupakan keyakinan akan kebenaran pikiran bahwa kehidupan bernegara haruslah rasional. Chauvinisme berarti prinsip politik dan perjuangan untuk menyesuaikan hidup bernegara yang benar dan sesuai (Moesa, 2007: 32).

Film For Sama merefleksikan sosok perempuan Wa'ad Al-Khateab yang berjuang di tengah konflik Suriah, tepatnya di Aleppo. Khususnya di masa Wa'ad di masa menjadi mahasiswa di Universitas Aleppo yang menyuarakan untuk menurunkan pemimpin yang dzolim. Wa'ad ikut berkontribusi dan turun ke lapangan untuk menyuarakan suara rakyat demi merebut keadilan dari kekuasan penguasa yang dzolim.

Latar scenenya demonstrasi besar mahasiswa Universitas Aleppo untuk menurunkan penguasa yang dzolim, Assad. Dan Wa'ad Al-Khateab menjadi orator bersuara lantang menyuarakan orasi, yaitu

Free students in Aleppo University! University of the revolution! Our revolution is peaceful. Muslim and Christians together. (monolog Wa'ad) At first the regime denied protests were even happening. Filming on mobile phones was the only way to show the world we were fighting for our freedom (For Sama, 2019, 09.45). 
Devi Laila Maghfiroh dan Moh. Zawawi, Resistensi Perempuan dalam Film For Sama: Kajian Timur Tengah Perspektif Feminisme Naomi Wolf

Orasi memperjuangkan keadilan dan kebebasan dari penguasa dzolim dilantangkan Wa'ad dengan sangat lantang dan membara. Wa'ad sebagai perempuan chauvinis yang gigih memperjuangkan kebebasan negaranya turun langsung ke lapangan tanpa rasa takut meskipun sebagian besar peserta demonstrasi adalah laki-laki. Nampak jelas dalam scene film yang mengawali awal terjadinya konflik besar di Suriah, Wa'ad mendokumentasikan dirinya terlibat dalam mengkritik kebijakan pemerintah, dan bertanya kepada teman-teman mahasiswa yang mulai memberikan pernyataan memberontak kepada pemimpin Suriah Assad. Keterlibatan Wa'ad memperjuangkan keadilan dan berani menolak kebijakan pemerintah ini menunjukkan kekuatan perempuan, dan esensi dari memperjuangkan gender perempuan dengan melibatkan diri dan membuktikkan diri sebagai perempuan yang berpotensi.

\section{Resistensi Revolusioner dalam Superioritas Perempuan}

Wolf mengatakan bahwa keberanian perempuanlah yang mampu memperbaiki kehidupan perempuan (Nasri, 2019, h. 372). Menjadi setara dan tidak tersubornatif ataupun termarginalkan adalah pilihan perempuan. Perempuan sudah seharusnya menjadi aktif dan memiliki keberanian sehingga menempatkannya pada posisi setara bukan sebatas objek. Perempuan pasiflah yang menjadi korban patriarki terkonstruk oleh stigma masyarakat. Perempuan revolusionerlah yang merubah pola pikir dan melakukan penggebrakan mental perempuan (Hearty, 2015: 117).

Keberanian perempuan adalah keharusan yang membangkitkan semangat dan penggerak revolusioner bangsa. Perempuan berhak menjadi pemegang peran utama yang memberikan komando dikarenakan perempuan memiliki posisi yang sama dengan laki-laki, perempuan memiliki hak kuasa yang sama dengan laki-laki (Fauziyah, 2015: xix). Perempuan yang berani adalah perempuan yang berani mendekonstruksi nilai-nilai patriarki (Meij, 2016: 80). Keberanian perempuan bukan berarti perempuan melakukan segala cara menjadi superioritas. Keberanian perempuan artinya perempuan mampu bertanggung jawab penuh atas peran gendernya (Sutarti, dkk., 2008: 39).

Film For Sama menempatkan posisi perempuan sebagai subjek superioritas yang berpengaruh besar. Film ini menunjukkan perempuan Wa'ad Al-Khateab sosok pemberani dan penggerak revolusioner di tengah konflik Suriah. Tidak hanya menjadi partisipan, tetapi Wa'ad memegang komando pemberi semangat dalam sebuah demonstrasi. Adapun scene 
Devi Laila Maghfiroh dan Moh. Zawawi, Resistensi Perempuan dalam Film For Sama: Kajian Timur Tengah Perspektif Feminisme Naomi Wolf

yang merefleksikannya adalah dimulai pada menit 10.14, dimana $\mathrm{Wa}$ 'ad terlibat langsung dalam demonstrasi dengan segala kericuhannya termasuk terlibat konflik dengan penjaga keamanan di wilayah tersebut. Wa'ad mendampingi teman terdekatnya Hamzah sebelum berstatus suami istri, Wa'ad terlibat aktif dalam demonstrasi penggerak revolusioner dan melihat secara langsung realitas akibat konflik Suriah yang menewaskan banyak korban dan semakin menguatkan keberaniannya (For Sama, 2019, 10.14).

Tidak sampai sebatas aktivis pejuang kebebasan Suriah, Wa'ad juga penggerak revolusioner di bidang jurnalistik yang menyuarakan revolusi Suriah ke seluruh penjuru dunia melalui internet. Wa'ad berjuang tanpa rasa takut dan memperoleh data penting untuk memperjuangkan kebebasan dengan tetap fokus mengambil video realitas konflik Suriah tentu dengan pertaruhan nyawanya. Adapun tuturannya yang merefleksikannya adalah sebagai berikut, di tengah pengeboman Rusia:

(monolog Wa'ad) I keep filming, it gives me a reason to be here, it makes the nightmares feel worthwhile (For Sama, 2019, 06.54).

Wa'ad memberanikan diri di tengah konflik berdarah di Aleppo, tetap berjuang mendokumentasikan untuk menyuarakan ke seluruh penjuru dunia revolusi Suriah demi kebebasan Suriah. Wa'ad mempertaruhkan nyawanya demi mendapatkan dokumentasi di tengah pengeboman Rusia yang terjadi terus menerus dan tak terduga objek bom yang dijatuhkannya. Wa'ad berkeinginan kuat terus berjuang dan berjuang tanpa henti, karena memang itulah alasannya tetap berada di Aleppo, di tengah konflik berdarah. Tidak hanya ditunjukkan sosok perempuan Wa'ad, masih banyak lagi perempuan-perempuan Suriah yang memilih tetap bertahan di Aleppo di tengah konflik.

"Not to worry Doctor, we're strong, we're resilient" (bersembunyi bersama ditengah pengeboman pesawat Rusia) (For Sama, 2019, 05.24).

Tuturan di atas di tuturkan oleh perempuan yang menggendong Sama pada waktu bersembunyi bersama-sama di ruangan paling bawah di tengah pengeboman pesawat Rusia termasuk Wa'ad dan Hamzah. Scene dengan tuturan di atas menunjukkan semangat keberanian perempuan di tengah keterpurukan akibat konflik Suriah. Bahkan dalam titik terendah warga Aleppo termasuk laki-laki akibat perang, perempuan tersebut masih memiliki semangat keberanian dan optimistis, bahkan suara menggebunya memotivasi mengusir psimistis warga Aleppo saat itu akibat tempat satu-satunya berlindung yaitu rumah sakit telah mendapati jatuhnya bom Rusia. 
Devi Laila Maghfiroh dan Moh. Zawawi, Resistensi Perempuan dalam Film For Sama: Kajian Timur Tengah Perspektif Feminisme Naomi Wolf

\section{Resistensi Ketangguhan Perempuan}

Sebagaimana Wolf mengatakan perempuan memilki kuasa untuk menentukan nasibnya sendiri. Feminisme kekuasaan Naomi Wolf menegaskan bahwa perempuan haruslah kuat dan tangguh sehingga tidak bergantung pada laki-laki dan terjerat nilai-nilai patriarki, dan tidak perlu meminta izin untuk mendapatkan kesetaraan gender. Perempuan berhak dan berkuasa penuh sebagai pemilik potensi dan kekuatan berdasarkan pengalamanpengalaman berharga dalam hidupnya (Hearty, 2015: 34).

Tangguh adalah pribadi yang mampu menentukan goal dalam hidupnya dan menjadi semangat dalam melakukan proses dalam hidupnya. Tangguh berarti media untuk mencapai keinginan terbesar dalam diri dan berusaha mewujudkannya (Ramdhani, dkk., 2018: 81). Tangguh artinya seseorang yang mampu membangun benteng termasuk kesabaran yang tinggi (Superival, 2014: 37)

Film For Sama mampu menunjukkan sosok perempuan Wa'ad Al-Khateab sebagai jurnalis perempuan di tengah konflik Suriah juga seorang ibu dari buah hati pertamanya bernama Sama. Wa'ad berada di tengah konflik Suriah sejak permulaan konflik tersebut terjadi, dan akhirnya memutuskan untuk menerima lamaran dari Hamzah, seorang dokter juga aktivis teman terdekatnya. Wa'ad dan Hamzah mendapat anugerah terbesar di tengah konflik Suriah tersebut lahirnya buah hati berjenis kelamin perempuan bernama Sama. Perjuangan seorang ibu dari awal kehamilan kemudian melahirkan, merawat hingga besar di tengah konflik berdarah dan kecemasan tiada akhir oleh puluhan bom yang dijatuhkan setiap harinya, bahkan hingga mengandung buah hati keduanya, menjadi ketangguhan luar biasa bagi perempuan. Adapun tuturan yang merefleksikannya adalah sebagai berikut:

I am pregnant again, My God, I can hardly find healthy food for myself or for you Sama, I don't know if your sister or brother will ever open their eyes (For Sama, 2019, 01.00.35).

Tuturan yang merefleksikan kekhawatiran seorang ibu akan kehidupan buah hatinya yang masih dalam kandungan, dan takut akan kehilangannya sebelum lahir. Mengandung, melahirkan, dan merawat sudah termasuk dalam ketangguhan perempuan, apalagi di tengah konflik berdarah dan korban terus bertambah juga kekhawatiran setiap detiknya. Wa'ad dengan posisi mengandung dan memiliki buah hati masih sangat mampu menjalankan kesibukan dan tanggungjawabnya setiap hari termasuk memperjuangkan kebebasan Suriah sebagai proses demi mencapai keinginan terbesarnya yaitu kebebasan Suriah bersamaan kebahagiaan dan kedamaian bersama keluarga kecilnya. 
Devi Laila Maghfiroh dan Moh. Zawawi, Resistensi Perempuan dalam Film For Sama: Kajian Timur Tengah Perspektif Feminisme Naomi Wolf

\section{Simpulan}

Berdasarkan hasil pembahasan peneliti dalam mensinkronkan tujuan penelitian, telah diperoleh simpulan yaitu: Dari hasil perolehan data dalam film For Sama, resistensi perempuan berdasarkan perspektif Naomi Wolf terdiri atas enam bentuk, yaitu: (1) independensi; (2) altruisme; (3) persistensi; (4) chauvinisme; (5) revolusioner; (6) ketangguhan. Independensi yang terefleksikan dalam kemandirian tokoh Wa'ad Al-Khateab tinggal jauh dari orangtua, menjadi mahasiswi Aleppo University. Altruisme yang tergambarkan dari cara pikir dan tindakan Wa'ad Al-Khateab yang mementingkan kepentingan oranglain tersmasuk banyak orang daripada kepentingan diri sendiri sebagai kepercayaan dirinya sebegai perempuan berpotensi dan memiliki kekuatan. Persisten Wa'ad nampak pada ketetapan hatinya untuk tinggal di Aleppo di tengah konflik berdarah dan memperjuangkannya dengan pertaruhan nyawa. Chauvinis Wa'ad mendarah daging dengan rela mempertaruhkan nyawa dan memiliki ketahanan yang kuat untuk hidup di tengah konflik demi keadilan pemimpin dan kebebasan Suriah, partisipasi aktif berdemonstrasi menyuarakan suara rakyat demi menurunkan pemimpin yang dzolim. Jiwa revolusioner Wa'ad sangat jelas mencuat dalam setiap scene film, berjuang penuh keberanian demi kebebasan Suriah, Wa'ad yang tetap bertanggungjawab atas setiap peran gendernya sebagai seorang ibu, istri, termasuk jurnalis yang berusaha sekuat mungkin melaksanakannya di tengah konflik, mengandung di tengah konflik dan tetap berusaha mendapatkan scene realita Suriah dengan mempertaruhkan nyawa demi kebebasan Suriah. Ketangguhan Wa'ad sangat teruji sebagai seorang ibu dari buah hatinya Sama, dan juga calon ibu untuk anak keduanya di dalam kandungan dengan kekhawatiran di setiap detiknya.

Berdasarkan hasil temuan peneliti dapat menyimpulkan bahwa fenomena resistensi perempuan dalam film For Sama menunjukkan realita konflik berdarah Suriah khususnya di Aleppo dan mampu merefleksikan resistensi perempuan sebagai seorang jurnalis, istri, dan seorang ibu berdasarkan perspektif Wolf khusunya pemikiran feminisme kekuasaan. Peneliti menyimpulkan bahwa resistensi perempuan dalam film dokumenter For Sama mampu menunjukkan feminisme kekuasaan pada perempuan Timur Tengah dan menolak stigma-stigma negatif yang terkonstruk sosial budaya. Hal ini dapat termanifestasi dalam segala aspek kehidupan di tengah konflik Suriah. 
Devi Laila Maghfiroh dan Moh. Zawawi, Resistensi Perempuan dalam Film For Sama: Kajian Timur Tengah Perspektif Feminisme Naomi Wolf

\section{Daftar Pustaka}

Achmadi, Abu dan Cholid Narbuko. Metodologi Penelitian. Penerbit: Bumi Aksara. Jakarta, 2002.

Anggraini, Purwati dan Tuti Kusniarti. Pembelajaran Sastra Indonesia Berbasis Kearifan Lokal. Penerbit: UMM Press. Malang, 2017.

Djajanegara, Soenarjati. Kritik Sastra Feminis: Sebuah Pengantar. Penerbit: Gramedia Pustaka. Yogyakarta, 2000.

Fauziyah, Ida. Geliat Perempuan Pasca-Reformasi. Penerbit: PT. LKiS Pelangi Aksara. Yogyakarta, 2015.

Gula, Richard M. Etika Pastoral. Terjemahan oleh William Chang. Penerbit: Kanisius. Yogyakarta, 2009.

Hammer, Rhonda. Antifeminism and Family Terrorism: A Critical Feminist Perspective. Publisher: Rowman and Littlefield Publisher Inc. Oxford, 2002.

Hearty, Free. Keadilan Jender: Perspektif Feminis Muslim dalam Sastra Timur Tengah. Penerbit: Yayasan Pustaka Obor Indonesia. Jakarta, 2015.

Irianto, Sulistyowati. Perempuan di antara Berbagai Pilihan Hukum. Penerbit: Yayasan Obor Indonesia. Jakarta, 2003.

Jones, Pip. Pengantar Teori-Teori Sosial: dari Teori Fungsionalisme hingga Post Modernisme, terj. Ahmad Fedyani Saifuddin. Penerbit: Yayasan Pustaka Obor Indonesia. Jakarta, 2009.

Majid, Novita. Penguatan Karakter melalui Local Wisdom. Penerbit: Yayasan Ahmar Cendekia Indonesia. Takalar, 2019.

Meij, Lim Sing. Ruang Sosial Baru Perempuan Tioghoa. Penerbit: Yayasan Pustaka Obor Indonesia. Jakarta, 2016.

Miles, Matthew B; A. Michael Huberman; and Johnny Saldana. Qualitative Data Analysis. Publisher: Sage Publications Inc. New York, 2014.

Moesa, Ali Maschan. Nasionalisme Kiai Konstruksi Sosial Berbasis Agama. Penerbit: LKiS Yogyakarta. Yogyakarta, 2007.

Murphy, Peter F. Feminism and Masculinities. Publisher: Oxford University Press. New York, 2004.

Muslimin, Muhammad Fadli. (2019). "Perempuan dalam Novel Destroy She Said karya Marguerite Duras: Analisis Feminisme Kekuasaan Naomi Wolf" dalam Jurnal Undas, Fakultas Sastra, Universitas Muslim Indonesia, Vol. 15, No. 2, Desember tahun 2019.

Nasri, Ulyan. Akar Historis Pendidikan Perempuan Refleksi Pemikiran TGKH. M. Zainuddin Abdul Madjid. Penerbit: Deepublish. Yogyakarta, 2019.

Rahman, Norhayati Ab dan Free Hearty. Kajian Perempuan Malaysia-Indonesia dalam Sastra. Penerbit: Yayasan Pustaka Obor Indonesia. Jakarta, 2016. 
Devi Laila Maghfiroh dan Moh. Zawawi, Resistensi Perempuan dalam Film For Sama: Kajian Timur Tengah Perspektif Feminisme Naomi Wolf

Ramdhani, Neila dkk. Psikologi untuk Indonesia Tangguh dan Bahagia. Penerbit: Gadjah Mada University Press. Yogyakarta, 2018.

Saleh, Kaerul. (2018). "Kapasitas Perempuan Perdesaan Pelaku Industri Rumahan Kampung Melinjo menuju Kemandirian Usaha di Provinsi Banten" dalam Buletin Agrosaintek Sulawesi Utara. Manado: Balai Pengkajian Teknologi Pertanian Sulawesi Utara.

Shihab, M. Quraish. Perempuan. Penerbit: Lentera Hati. Tangerang, 2010.

Superival. Tangguh Perkasa. Penerbit: CV. Rasi Terbit. Bandung, 2014.

Sutarti, Nurul dkk. Menyibak Tabir Perempuan Berpolitik. Penerbit: Yayasan Krida Paramida Surakarta. Surakarta, 2008.

Tracy, Sarah J. Qualitative Research Methods. Publisher: Blackwell. United Kingdom, 2013.

Udasmoro, Wening. Dari Doing ke Undoing Gender. Penerbit: Gadjah Mada University Press. Yogyakarta, 2018.

Wolf, N. Geger Gender. Penerbit: Pustaka Semesta Press. Yogyakarta, 1997.

Yin, Robert K. Qualitative Research from Start to Finish. Publisher: The Guilford Press. New York, 2011. 